\title{
PENYUSUNAN LAPORAN KEUANGAN BERDASARKAN STANDAR AKUNTANSI KEUANGAN ENTITAS TANPA AKUNTABILITAS PUBLIK NO. 5 PADA HOTEL BOULEVARD
}

\author{
Halim Ellena Muliadi ${ }^{1}$, Stanly W. Alexander ${ }^{2}$, Hendrik Gamaliel $^{2}$ \\ ${ }^{1,2}$ Jurusan Akuntansi, Fakultas Ekonomi dan Bisnis, Universitas Sam Ratulangi, Kampus Unsrat, Sulawesi \\ Utara, 95115, Indonesia \\ ${ }^{1}$ E-mail: halimellena@gmail.com
}

\begin{abstract}
Income statement is a report that describes the success of a company in carrying out its business activities. In this case, Boulevard Hotel in recording the income statement is still very simple not in accordance with applicable financial standards, namely Accounting Standard Non Publicly Accountable Entities (SAK ETAP). This study aims to make an income statement and describe and compare the results of the calculation of revenues, costs and profits based on SAK ETAP with the results of the calculation applied by Hotel Boulevard. This research is a descriptive qualitative research. The research method used is descriptive method that is describing the results of research in accordance with the facts found in the field. The results obtained indicate that Boulevard Hotel has not prepared financial reports in accordance with SAK ETAP No. 5.
\end{abstract}

Keywords: income statements; SAK ETAP; revenue; expense; profit.

\section{PENDAHULUAN}

Pada mulanya laporan keuangan bagi suatu perusahaan hanya sebagai alat penguji dari pekerjaan bagian pembukuan. Selanjutnya, laporan keuangan tidak hanya sebagai alat penguji saja, tetapi juga sebagai dasar untuk dapat menentukan atau menilai posisi keuangan perusahaan yang bersangkutan dengan melakukan analisis kinerja keuangan. Melalui hasil analisis tersebut, dapat diketahui pengunaan sumber-sumber ekonomi, kewajiban yang harus dipenuhi dan modal yang dimiliki oleh perusahaan, serta hasil-hasil yang telah dicapai perusahaan tersebut. Laporan keuangan adalah gambaran tentang hasil atau perkembangan usaha perusahaan. Laporan keuangan tersebut digunakan untuk membantu para pemakai laporan keuangan dalam menilai kinerja perusahaan sehingga dapat mengambil keputusan yang tepat (Rama, 2015:5).

Hotel Boulevard adalah salah satu perusahaan yang bergerak dalam bidang jasa. Pelayanan jasa yang diberikan oleh Hotel Boulevard hanya layanan kamar kepada tamu. Pencatatan administrasi yang dilakukan oleh pihak Hotel Boulevard masih secara konvensional yaitu hanya sebatas pada mencatat dalam buku penerimaan kas dan pengeluaran kas. Kemudian catatan penerimaan dan pengeluaran kas ini akan direkap setiap bulannya untuk mengetahui seluruh transaksi yang terjadi. Hotel Boulevard termasuk dalam perusahaan yang belum go public. Sehingga, dalam melakukan penyusunan laporan keuangan perlu penggunaan SAK ETAP.

\section{TINJAUAN PUSTAKA}

Pengertian akuntansi. Menurut Suwardjono (2015:10), akuntansi dapat didefinisikan sebagai seperangkat yang mempelajari perekayasaan penyediaan jasa berupa informasi keuangan kuantitatif unit-unit organisasi dalam suatu lingkungan negara tertentu dan cara penyampaian (pelaporan) informasi tersebut kepada pihak yang berkepentingan untuk dijadikan dasar dalam pengambilan keputusan ekonomik. Menurut Effendi (2013:1) 
akuntansi merupakan proses pengidentifikasian, pengukuran, pencatatan, penggolongan, dan pengikhtisaran serta pelaporan informasi keuangan dalam ukuran moneter (uang) dalam suatu perusahaan atau organisasi yang ditujukan kepada pihak-pihak yang berkepentingan dalam rangka pengambilan keputusan.

Siklus akuntansi. Menurut Bahri (2016:18), siklus akuntansi adalah tahapan-tahapan mulai dari terjadinya transaksi sampai dengan penyusunan laporan keuangan sehingga siap untuk pencatatan berikutnya. Menurut Syakur (2015:3), siklus akuntansi terjadi dalam satu periode, satu periode akuntansi berumur 12 bulan yang dapat mengikuti tahun kalender (tahun takwim) yang diawali tanggal 1 Januari dan diakhiri pada tanggal 31 Desember, atau berdasarkan periode tertentu.

Pengertian hotel. Menurut Sulastiyono (2011:15), hotel adalah suatu perusahaan yang dikelola oleh pemiliknya dengan menyediakan pelayanan makanan, minuman dan fasilitas kamar untuk tidur kepada orang-orang yang melakukan perjalanan dan mampu membayar dengan jumlah yang wajar sesuai dengan pelayanan yang diterima tanpa adanya perjanjian khusus.

Akuntansi perhotelan. Akuntansi bertujuan memberikan informasi mengenai operasional hotel. Dengan informasi keuangan ini, manajemen akan dapat mengambil keputusan yang lebih tepat. Manajemen memerlukan informasi keuangan dengan tujuan perencanaan, analisis dan pengendalian. Dengan informasi keuangan yang sekarang, manajemen dapat merencanakan kegiatan periode yang akan datang (Wiyasha, 2011:39).

Standar Akuntansi Keuangan Entitas Tanpa Akuntabilitas Publik. Menurut SAK ETAP (2019:1), ciri dari entitas tanpa akuntabilitas publik yaitu, tidak memiliki akuntabilitas publik signifikan dan menerbitkan laporan keuangan untuk tujuan umum (general purpose financial statement) bagi pengguna eksternal. Contoh pengguna eksternal adalah pemilik yang tidak terlibat langsung dalam pengelolaan usaha, kreditur, dan lembaga pemeringkat kredit.

Pengertian pendapatan. Menurut SAK ETAP (2019:121), pendapatan adalah arus masuk bruto dari manfaat ekonomi yang timbul dari aktivitas normal entitas selama suatu periode ketika arus masuk itu mengakibatkan kenaikan ekuitas, yang tidak berasal dari kontribusi penanam modal. Menurut Martani et al. (2016:204), penghasilan adalah kenaikan manfaat ekonomi selama suatu periode akuntansi dalam bentuk pemasukan atau penambahan aset atau penurunan liabilitas yang mengakibatkan kenaikan ekuitas yang tidak berasal dari kontribusi penanam modal.

Klasifikasi pendapatan. Menurut Panggabean (2015), pendapatan dapat diklasifikasikan menjadi dua, yaitu pendapatan operasional dan pendapatan non operasional. Pendapatan operasional adalah pendapatan yang timbul dari penjualan barang dagangan, produk, atau jasa dalam periode tertentu dalam rangka kegiatan utama atau yang menjadi tujuan utama perusahaan yang berhubungan langsung dengan usaha (operasi) pokok perusahaan yang bersangkutan. Pendapatan ini sifatnya normal sesuai dengan tujuan dan usaha perusahaan dan terjadinya berulang-ulang selama perusahaan melangsungkan kegiatannya.

Pengakuan pendapatan. Salah satu permasalahan utama dari elemen pendapatan adalah proses pengakuan pendapatan (revenue recognition). Pengakuan (recognition) mengacu pada saat atau waktu dimana suatu transaksi tersebut, baik dalam kata-kata maupun jumlahnya, dimana jumlahnya mencakup angka-angka ringkas yang dilaporkan dalam laporan keuangan (Datulangie dan Poputra, 2016). Menurut Hutabarat (2017), metode dalam pencatatan pendapatan terdiri dari dua metode, yaitu metode berbasis kas (cash basis method) dan metode berbasis akrual (accrual basis method). Metode kas basis adalah suatu sistem dimana pendapatan belum diakui sebelum pendapatan tersebut belum diterima. Sedangkan 
metode akrual basis adalah metode pencatatan pendapatan, dimana pendapatan itu dicatat pada saat sudah terjadi hak tanpa memperhatikan pendapatan tersebut diterima.

Pengertian beban dan biaya. Istilah biaya (cost) sering digunakan dalam arti yang sama dengan istilah beban (expense). Berdasarkan teori yang ada istilah biaya (cost) dengan istilah beban (expense) merupakan dua hal yang berbeda. Bustami dan Nurlela (2010:4), mengemukakan pengertian biaya dan beban sebagai berikut:

1. Biaya (cost) adalah pengorbanan sumber ekonomi yang diukur dalam satuan uang yang telah terjadi atau kemungkinan akan terjadi untuk mencapai tujuan tertentu. Biaya ini belum habis masa pakainya dan digolongkan sebagai aktiva yang dimasukkan kedalam neraca.

2. Beban (expense) adalah biaya yang telah memberikan manfaat dan sekarang telah habis. Biaya yang belum dinikmati yang dapat memberikan manfaat di masa yang akan datang dikelompokkan sebagai harta. Beban ini dimasukkan kedalam laporan laba atau rugi, sebagai pengurangan pendapatan.

Berdasarkan definisi tersebut ditarik kesimpulan bahwa biaya adalah pengeluaran yang digunakan sebagai pengorbanan untuk menghasilkan suatu produk atau jasa dan beban adalah pengeluaran yang digunakan untuk membantu dalam proses perolehan barang atau jasa yang mempengaruhi pendapatan.

Pengakuan beban. Perusahaan dalam melaksanakan operasinya menggunakan sumber daya, yang digunakan haruslah dialokasikan dalam hal ini sebagai beban. Beban diakui dalam laporan laba rugi kalau penurunan manfaat ekonomi masa depan yang berkaitan dengan penurunan aktiva atau peningkatan kewajiban telah terjadi dan dapat diukur dengan andal. Ini berarti pengakuan beban terjadi bersamaan dengan pengakuan kenaikan kewajiban atau penurunan aktiva, misalnya penurunan aktiva tetap (Silaban, 2018).

Laporan laba rugi. Laporan laba rugi adalah laporan keuangan yang menyajikan informasi mengenai kinerja entitas selama satu periode, yaitu hubungan penghasilan dan beban (IAI, 2019). Menurut Panggabean (2015), laporan laba rugi membantu memprediksi arus kas masa depan dengan berbagai cara agar investor dan kreditor dapat diinformasikan tersebut untuk (a) mengevaluasi kinerja masa lalu perusahaan; (b) memberikan dasar untuk memprediksi kinerja masa depan; (c) membantu menilai resiko atau ketidakpastian pencapaian arus kas masa depan.

Penelitian terdahulu. Oktaliza (2015), menunjukkan bahwa CV. Kepala Jaya masih belum membuat laporan keuangan berdasarkan SAK ETAP, karena keterbatasan pengetahuan mengenai akuntansi. Basyarullah (2018), menunjukkan Klinik Musik Surabaya belum menyajikan laporan keuangan sesuai SAK ETAP. Oktari (2019), Hasil penelitian menunjukkan $\mathrm{CV}$. Tugu Indah belum sepenuhnya melakukan pembukuan sesuai dengan ketentuan laporan keuangan SAK ETAP. Hasil penelitian Sumendap et al. (2015) menunjukkan bahwa Bank Perkreditan Rakyat Cipta Cemerlang Indonesia telah melakukan penyajian laporan keuangan lengkap namun belum melakukan pengungkapan reklasifikasi pada catatan atas laporan keuangan.

\section{METODE PENELITIAN}

Jenis penelitian ini adalah kualitatif deskriptif. Jenis penelitian ini dipilih karena peneliti bertujuan untuk menyusun laporan keuangan laba rugi berdasarkan SAK ETAP No. 5 dan mendeskripsikan serta membandingkan hasil penyusunan laporan laba rugi berbasis pada Standar Akuntansi Keuangan Entitas Tanpa Akuntabilitas Publik (SAK ETAP) No. 5 dengan hasil penyusunan laba rugi milik Hotel Boulevard.Penelitian ini dilakukan pada Hotel Boulevard di Jalan. Ahmad Yani 13, Sario Tumpaan, Manado, Sulawesi Utara.

Berdasarkan jenisnya, data penelitian ini dikelompokkan menjadi dua, yaitu (1) data kualitatif yang dibutuhkan dalam penelitian ini seperti pengumpulan data dokumentasi berupa 
sejarah, struktur organisasi hotel, sistem pembuatan laporan keuangan, serta hasil wawancara yang diperoleh secara langsung dari objek penelitian; dan (2) data kuantitatif yang diperlukan dalam penelitian ini adalah seperti data transaksi hotel seperti penjualan atas jasa kamar, data rincian pendapatan dan beban, serta laporan keuangan laba rugi untuk tahun 2018 dan 2019.

Sumber data yang digunakan dalam penelitian ini adalah data primer, yaitu dimana data secara langsung didapatkan atau dikumpulkan dari objek penelitian yaitu Hotel Boulevard. Metode pengumpulan data yang digunakan dalam penelitian ini adalah: (1) wawancara yaitu melakukan tanya jawab secara langsung kepada pihak manajer Hotel Boulevard dan pihak administrasi; dan (2) dokumentasi yaitu mengamati dan mengumpulkan data-data yang diperlukan mengenai penyusunan laporan keuangan.

\section{HASIL PENELITIAN DAN PEMBAHASAN}

\subsection{Hasil penelitian}

Laporan laba rugi berdasarkan SAK ETAP. Laporan laba rugi adalah laporan yang menunjukkan kemampuan atau kinerja dari suatu perusahaan dalam satu periode. Laporan laba rugi berisikan akun pendapatan yang diperoleh suatu perusahaan berdasarkan aktivitas perusahaan serta berisikan akun beban yaitu pengorbanan ekonomis yang dilakukan oleh perusahaan dalam memperoleh barang atau jasa dalam rangka menjalankan aktivitas perusahaan pada suatu periode. Dalam menjalankan aktivitas bisnisnya, Hotel Boulevard tidak membuat laporan keuangan terlebih khusus laporan laba rugi yang sesuai dengan SAK ETAP. Berikut laporan laba rugi untuk Hotel Boulevard sesuai dengan SAK ETAP.

Tabel 1. Laporan laba rugi Hotel Boulevard per 31 Desember 2019 sesuai SAK ETAP

Pendapatan Usaha

Pendapatan Kamar

Rp. 1.469 .110 .500

Beban Usaha

Beban Gaji Karyawan

Beban Telepon

Beban Air

Beban Listrik

Beban Pemeliharaan

Beban Perlengkapan Laundry

Beban Perlengkapan Kantor

Beban Pajak Bumi Bangunan

Beban BPJS Ketenagakerjaan

Beban Penyusutan Bangunan

Beban Penyusutan Peralatan Hotel

Beban Penyusutan Peralatan Kantor

Total Beban Usaha

Laba Sebelum Pajak

Beban Pajak Penghasilan

Laba Bersih

Sumber : Data olah, 2020
Rp. 732.000 .000

Rp. 14.400 .000

Rp. 27.717 .000

Rp. 138.020 .000

Rp. 18.500 .000

Rp. 7.771 .000

Rp. 875.000

Rp. 11.146 .900

Rp. 84.000 .000

Rp. 120.000 .000

Rp. 38.943 .000

Rp. 2.835.000
Rp. 1.196.207.900

Rp. 272.902 .600

Rp. 143.944.550

Rp. 128.958.050

Pendapatan Hotel Boulevard sesuai SAK ETAP. Pendapatan yang ada di Hotel Boulevard diperoleh dari pendapatan atas penjualan kamar. Berdasarkan penyusunan laba rugi yang sesuai dengan SAK ETAP diketahui bahwa total pendapatan atas penjualan kamar yang dimiliki oleh Hotel Boulevard untuk tahun 2019 adalah sebesar Rp. 1.469.110.500.

Beban Hotel Boulevard sesuai SAK ETAP. Hotel Boulevard dalam menjalankan aktivitas bisnisnya pastinya melakukan pengeluaran dalam hal ini beban-beban dalam mendukung aktivitas bisnisnya. Beban yang ada didalam Hotel Boulevard terdiri atas beban 
gaji, beban telepon, beban air, beban listrik, beban pemeliharaan, beban Badan Penyelenggara Jaminan Sosial (BPJS), beban Pajak Bumi Bangunan (PBB), beban perlengkapan kantor dan laundry, beban penyusutan bangunan dan peralatan. Berdasarkan perhitungan yang sesuai dengan SAK ETAP diketahui besaran beban yang dimiliki oleh Hotel Boulevard untuk tahun 2019 adalah sebesar Rp. 1.196.207.900.

Laba Hotel Boulevard sesuai SAK ETAP. Perhitungan laba dilakukan dengan mengurangi seluruh total pendapatan dan beban lalu didapatkan laba sebelum pajak sebesar Rp. 272.902.600. Setelah itu dikurangi dengan pajak penghasilan, maka diketahui bahwa laba bersih yang dihasilkan oleh Hotel Boulevard untuk tahun 2019 adalah sebesar Rp. 128.958.050.

\subsection{Pembahasan}

Hotel Boulevard adalah perusahaan yang belum go public, maka perlu penggunaan SAK ETAP dalam hal penyusunan laporan keuangan. Hotel Boulevard dari awal berdiri sampai sekarang tidak membuat laporan keuangan laba rugi yang sesuai dengan SAK ETAP. Sebab administrasi yang selama ini di buat oleh Hotel Boulevard masih secara konvensional hanya sebatas dalam mencatat dalam buku kas. Hal ini dikarenakan pihak Hotel Boulevard belum sepenuhnya mengetahui bagaimana penerapan standar akuntansi keuangan terlebih khusus SAK ETAP. Oleh karena itu, laporan laba rugi yang dibuat oleh pihak Hotel Boulevard terdapat beberapa kesalahan pencatatan yang harusnya dicatat dalam laporan laba rugi namun tidak dicatat. Maka sebaiknya Hotel Boulevard dalam melakukan penerapan dengan SAK ETAP dapat merekrut karyawan yang lebih kompeten dalam bidang akuntansi agar dapat terhindar dari kesalahan dalam pencatatan dan menghasilkan informasi keuangan yang akurat.

Tabel 2. Perbandingan laporan laba rugi Hotel Boulevard dan SAK ETAP

\begin{tabular}{lll}
\hline Keterangan & Disusun oleh Hotel Boulevard & Disusun SAK ETAP \\
\hline A. Pendapatan & & \\
Pendapatan Kamar & 1.469 .110 .500 & 1.469 .110 .500 \\
B. Beban Usaha & & \\
Beban Gaji Karyawan & 732.000 .000 & 732.000 .000 \\
Beban Telepon & 14.400 .000 & 14.400 .000 \\
Beban Air & 27.717 .000 & 27.717 .000 \\
Beban Listrik & 138.020 .000 & 138.020 .000 \\
Beban Pemeliharaan & 18.500 .000 & 18.500 .000 \\
Beban Perlengkapan Laundry & 8.129 .000 & 7.771 .000 \\
Beban Perlengkapan Kantor & 1.000 .000 & 875.000 \\
Beban Pajak Bumi Bangunan & 11.146 .900 & 11.146 .900 \\
Beban BPJS Ketenagakerjaan & 84.000 .000 & 84.000 .000 \\
Beban Penyusutan Bangunan & - & 120.000 .000 \\
Beban Penyusutan Perlatan Hotel & - & 38.943 .000 \\
Beban Penyusutan Peralatan Kantor & - & 2.835 .000 \\
Total Beban Usaha & 1.034 .912 .900 & 1.196 .207 .900 \\
Laba Sebelum Pajak & 434.110 .500 & 272.902 .600 \\
Beban Pajak Penghasilan & 143.944 .550 & 143.944 .550 \\
Laba Bersih & 290.253 .050 & 128.958 .050 \\
\hline Sa & &
\end{tabular}

Sumber : Data olah, 2020

Berdasarkan tabel perbandingan diatas dapat dilihat terdapat persamaan dan perbedaan antara pendapatan, beban dan laba yang dimiliki oleh Hotel Boulevard dan perhitungan berdasarkan SAK ETAP. Pendapatan yang dimiliki oleh Hotel Boulevard hasilnya sama dengan perhitungan berdasarkan SAK ETAP yaitu sebesar Rp. 1.469.110.500. 
Sedangkan untuk akun beban dan laba terdapat perbedaan. Pada akun beban yang berdasarkan Hotel Boulevard memiliki hasil sebesar Rp. 1.034.912.900. Sedangkan pada akun beban berdasarkan perhitungan sesuai SAK ETAP didapat hasil sebesar Rp. 1.196.207.900. Lalu pada akun laba terdapat perbedaan yaitu hasil pada Hotel Boulevard laba yang dimiliki sebesar Rp. 290.253.050 dan pada laba yang sesuai dengan SAK ETAP didapatkan hasil Rp. 128.958.050.

Berdasarkan kekeliruan dalam pencatatan tersebut menghasilkan beban yang berbeda dan total laba yang dihasilkan oleh Hotel Boulevard juga berbeda. Namun terdapat juga persamaan atas akun pendapatan yang dimiliki oleh Hotel Boulevard dengan penyusunan laporan laba rugi berdasarkan SAK ETAP yaitu tercatat sebesar Rp. 1.469.110.500. Penyusunan laporan laba rugi milik Hotel Boulevard terdapat saldo akun yang belum sesuai dengan SAK ETAP yang mengakibatkan selisih perbedaan yaitu beban sebesar Rp. 161.295.000. Perbedaan ini disebabkan karena Hotel Boulevard tidak melakukan penyesuaian beban yang telah terpakai dalam periode 2019 atas akun beban perlengkapan kantor dan hotel serta tidak melakukan penyesuaian atas aset tetap bangunan, peralatan kantor dan hotel. Sebab dalam SAK ETAP No. 5 tentang laba rugi mengharuskan entitas mengklasifikasikan beban berdasarkan fungsi mengungkapkan informasi tambahan berdasarkan sifat beban termasuk penyusutan. Berdasarkan pencatatan yang dimiliki oleh Hotel Boulevard terdapat perbedaan yaitu tercatat laba bersih sebesar Rp. 290.253.050, sedangkan dalam penyusunan laba rugi yang sesuai dengan SAK ETAP mendapatkan hasil yang berbeda yaitu sebesar Rp. 128.958.050. Oleh karenanya, terdapat selisih hasil sebesar Rp. 161.295.000.

\section{KESIMPULAN DAN SARAN \\ 5.1. Kesimpulan}

Berdasarkan penelitian yang dilakukan dapat ditarik kesimpulan sebagai berikut:

1. Hotel Boulevard adalah perusahaan yang belum go public sehingga perlu menggunakan Standar Akuntansi Keuangan Entitas Tanpa Akuntabilitas Publik (SAK ETAP). Hotel Boulevard dalam melakukan pencatatan atas laporan keuangan laba rugi belum mengikuti standar akuntansi keuangan yang berlaku yaitu SAK ETAP. Hal tersebut dikarenakan manajemen Hotel Boulevard masih belum sepenuhnya mengetahui bagaimana melakukan penyusunan laporan keuangan berdasarkan SAK ETAP.

2. Pendapatan yang dimiliki oleh Hotel Boulevard hasilnya sama dengan perhitungan berdasarkan SAK ETAP yaitu sebesar Rp. 1.469.110.500. Sedangkan untuk akun beban dan laba terdapat perbedaan. Pada akun beban yang berdasarkan Hotel Boulevard memiliki hasil sebesar Rp. 1.034.912.900. Sedangkan pada akun beban berdasarkan perhitungan sesuai SAK ETAP didapat hasil sebesar Rp. 1.196.207.900. Lalu pada akun laba terdapat perbedaan yaitu hasil pada Hotel Boulevard laba yang dimiliki sebesar Rp. 290.253.050 dan pada laba yang sesuai dengan SAK ETAP didapatkan hasil Rp. 128.958.050.

\subsection{Saran}

Berdasarkan kesimpulan sebelumnya, maka saran yang dapat diberikan peneliti yaitu: (1) pihak Hotel Boulevard diharapkan dapat melakukan pencatatan atau pembukuan keuangan yang sesuai dengan SAK ETAP terlebih khusus pada pencatatan akun beban sebab Hotel Boulevard tidak melakukan penyesuaian beban yang telah terpakai dalam periode 2019 atas akun beban perlengkapan kantor dan hotel serta tidak melakukan penyesuaian atas aset tetap bangunan, peralatan kantor dan hotel sehingga nantinya dapat memberikan informasi keuangan yang akurat serta dapat dijadikan bahan evaluasi atas kinerja dari Hotel Boulevard dan dapat memberikan manfaat baik pihak internal dan eksternal untuk perkembangan usaha dimasa depan; dan (2) sebaiknya Hotel Boulevard dalam melakukan penerapan SAK ETAP 
dapat merekrut karyawan yang lebih kompeten dalam bidang akuntansi agar dapat terhindar dari kesalahan dalam pencatatan dan menghasilkan informasi keuangan yang akurat.

\section{DAFTAR PUSTAKA}

Bahri, S. (2016). Pengantar akuntansi berdasarkan SAK ETAP dan IFRS. Jakarta: Penerbit Andi.

Basyarullah, R. (2018). Implementasi penyajian laporan keuangan pada Klinik Musik Surabaya berdasarkan standar akuntansi keuangan entitas tanpa akuntabilitas publik. Skripsi. Universitas Islam Negeri Sunan Ampel. http://digilib.uinsby.ac.id/25508/7/Rezka\%20Basyarullah_G92214036.pdf

Bustami., \& Nurlela. (2010). Akuntansi biaya, Edisi 2. Jakarta: Mitra Wacana Media.

Datulangie, R. M., \& Poputra, A. T. (2016). Analisis pengakuan pendapatan dan beban pada PT. Pegadaian (persero) cabang megamas. Jurnal Accountability, 5(1), 1-5. https://doi.org/10.32400/ja.11868.5.1.2016.26-30

Effendi, R. (2013). Accounting principles prinsip-prinsip akuntansi berbasis SAK ETAP, Cetakan kedua. Jakarta: Raja Grafindo Persada.

Hutabarat, D. A. (2017). Analisis penerapan PSAK 34 terhadap pendapatan jasa konstruksi (Studi kasus PT. Paramita Bangun Sarana, Tbk). Skripsi. Universitas Bakrie. Jakarta. http://repository.bakrie.ac.id/840/

Martani, D., Siregar, V. S., Wardhani, R., Farahmita, A., \& Tanujaya, E. (2016). Akuntansi keuangan menengah berbasis PSAK. Jakarta: Salemba Empat.

Oktaliza, I. (2015). Penyusunan laporan keuangan berbasis SAK ETAP pada CV. Kelapa Jaya Banyuasin. Skripsi. Universitas Muhammadiyah Palembang. http://repository.um-palembang.ac.id/id/eprint/1069/

Oktari, A. F. A. (2019). Implementasi laporan keuangan berdasarkan Standar Akuntansi Keuangan untuk Entitas Tanpa Akuntabilitas Publik (SAK- ETAP) pada CV. Tugu Indah. Jurnal Ilmiah Mahasiswa FEB, 8(1), 1-15. https://jimfeb.ub.ac.id/index.php/jimfeb/article/view/6233/5469

Panggabean, H. S. (2015). Analisis penerapan metode pengakuan pendapatan dan beban pada perum perumnas regional I Medan (PSAK No. 44) dibandingkan dengan SAK No. 23 dalam kaitannya dengan kewajaran penyajian laba rugi. Skripsi. Universitas Medan Area. http://repository.uma.ac.id/handle/123456789/742

Rama, S. A. (2015). Analisis laporan keuangan untuk mengukur kinerja keuangan studi pada PT. Mitra Pratama Mobilindo di Sukoharjo tahun 2009-2013. Skripsi. Universitas Muhammadiyah Solo. http://eprints.ums.ac.id/37075/

Silaban, A. (2018). Analisis pengakuan pendapatan dan beban pada Hotel Sedayu Parapat. Skripsi. Universitas HKBP Nommensen. http://repository.uhn.ac.id/handle/123456789/1553?show=full

Standar Akuntansi Keuangan Entitas Tanpa Akuntabilitas Publik (SAK ETAP). (2019). Laporan Laba Rugi. Dewan Standar Akuntansi Keuangan. Jakarta. Ikatan Akuntan Indonesia.

Sumendap, P. C., Saerang, D. P. E., \& Budiarso, N. S. (2015). Evaluasi penerapan 'SAK ETAP' Pada PT. Bank Perkreditan Rakyat Cipta Cemerlang Indonesia. Jurnal Berkala Efisiensi, 15(4), 493-504. https://ejournal.unsrat.ac.id/index.php/jbie/issue/view/1146

Sulastiyono, A. (2011). Manajemen penyelenggaraan hotel manajemen hotel. Bandung: Alfabeta. 
Suwardjono. (2015). Teori akuntansi perekayasaan laporan keuangan, Edisi 3. Yogyakarta: BPFE.

Syakur, S. A. (2015). Intermediate accounting. Jakarta: AV Publisher.

Wiyasha, I. B. M. (2011). Akuntansi perhotelan penerapan uniform system of accounts. Jakarta: Penerbit Andi. 